\title{
Integration of Renewable Energy Sources to Operate in Microgrids in Rural Zones in Brazil
}

\author{
Maria Luiza E. Bareta ${ }^{1}$ \\ https://orcid.org/0000-0001-8448-6260
}

Álvaro A. Sandim ${ }^{1}$

https://orcid.org/0000-0002-7124-2635

\author{
Alexandre G. Batista ${ }^{1 *}$ \\ https://orcid.org/0000-0002-7419-4544 \\ Roberto C. Betini ${ }^{2}$ \\ https://orcid.org/0000-0003-1817-6330
}

\author{
Luiz A. Pepplow ${ }^{1 *}$ \\ https://orcid.org/0000-0001-8124-1778
}

1 Universidade Tecnológica Federal do Paraná, Electrical Engineering, Curitiba, Brazil;

2 Universidade Tecnológica Federal do Paraná Electrotechnology Department, Curitiba, Brazil

Received: 2018.11.05; Accepted: 2019.07.26.

* Correspondence: alvaroafonso10@gmail.com; Tel.: +55-41-984635397 (A.A.S); alejjunior@gmail.com; (A.G.B); mlbareta1460@gmail.com; (M.L.E.B); betini@utfpr.edu.br; (R.C.B); luizpepplow@utfpr.edu.br; (L.A.P)

\section{HIGHLIGHTS}

- Proposed one microgrid to operate in Brazilian rural zones.

Abstract: In a world where technology is even more essential, quality and reliability of electrical system are fundamental. In Brazil, country where most of the energy is produced thought power plants, the existing distribution network is overwhelmed and the needs for the consolidation of distributed generation is growing. Wind and Solar power generation from biomass and another renewable sources are one alternative to power plants, which requires large areas and massive investment. The renewable energy sources mentioned may be assembled in a way to generate reliable energy to properties far from the cities, such as rural zones, where often energy from power plants doesn't gets to. Distributed generation allows quick development of Brazilian farming and guarantees to the farmer independence from the energy dealerships. Microgrids assembled with renewable sources are one sustainable option and benefits Brazilian economy and society.

Keywords: Microgrid, renewable energy, rural zones, distributed generation, energy potential.

\section{INTRODUCTION}

A few years are gone since Brazil had one of the most reliable, flexible, clean and cheap energy productions in the world. The infrastructure development for energy 
production didn't followed the country growth, today the Brazilian energetic field demands several improvements. Despite plentiful natural resources, which makes power generation in Brazil easier than in other countries, electrical fare in Brazil is among the highest in the world. At State Paraná the conventional fare charged by Copel (electrical company) in 2018 is $R \$ 0,53827$ for kWh, of which 0,18301 (34\%) are taxes. The high prices charged for electricity makes process more expensive, this makes Brazil low competitive on the international market, causing unemployment. Known for being a big exporter of farming products, Brazil must modernize farms to increase productivity, rural employment and the profits of farm workers. As the distribution networks are already running on maximum capacity, the growth of those requires high government investment and long-term buildings. The short-term solution, which benefits many aspects, is the implementation of microgrids in rural zones. The microgrids to be implemented uses as energy sources natural and renewable resources, such as biomass, wind, sun and heat. Figure 1 shows a schematic of the ideal microgrid compose. This research's objectives to show ways to use the energy potential existing in rural zones willing self-sufficiency of the farmers and one possible new revenue source through energy sale. Some energy types to be approached by this article are: wind, sun and biomass.

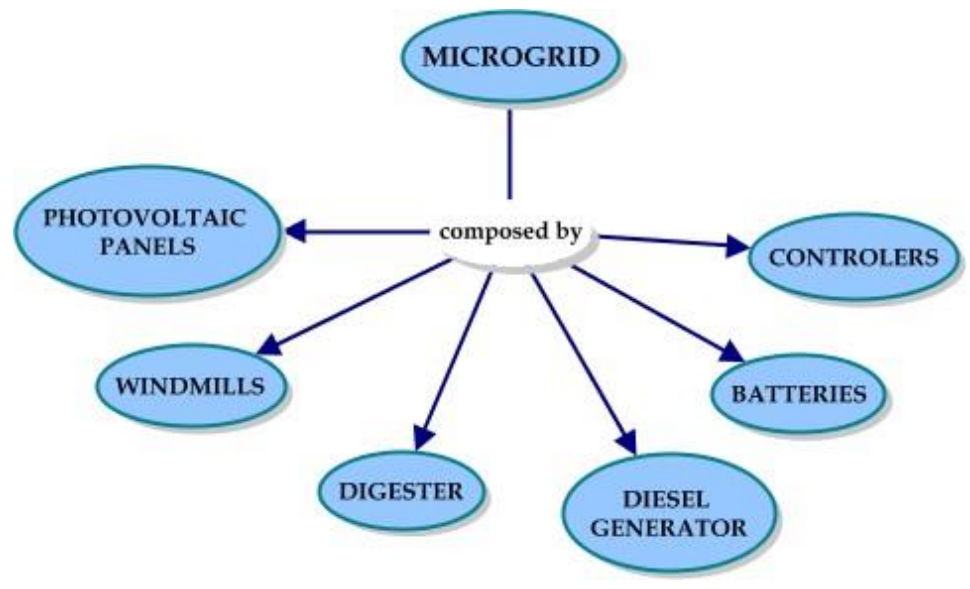

Figure 1. Ideal Microgrid Schematic.

\section{MATERIAL AND METHODS}

To get to the presented situation was made bibliographic study in international magazines published articles. The verification of the microgrid implementation viability at Brazil was done by the potential analysis of each energy sources mentioned and through microgrids that already are successful around the world.

\section{RESULTS}

\section{Solar Energy}

Beyond being an energy clean and renewable, sun energy is one great option to generate energy near to the client site. It is still expensive technology, however, with researches development and investment increases its tendency is to be even more accessible. This energy production method doesn't demand many maintenances and allows to store the production exceeding energy. Exist two types of solar energy production: heliothermic and photovoltaic. The first mentioned converts sun energy to thermic, the second one converts directly into electrical energy. One photovoltaic production problem is how to discard the photovoltaic plates, once they don't work 
anymore demands appropriate treatment, however it's only few disadvantages compared to many benefits [1].

Due to the proximity to Equator line, Brazil has huge energetic potential, its territory receives high incidence of sunbeams. According to Solar Atlas from 2006, Bahia is the Brazilian state with highest sunbeams incidence, by the other hand, the state that receives the lowest sunbeam incidence is Santa Catarina [1]. Paraná has one enormous potential to be explored, on the Atlas Solar Paraná website is possible to see the radiation rate in all areas of the state, for example, in Curitiba the global horizontal irradiation rate is $1500-1600 \mathrm{kWh} / \mathrm{m} 2$.year [2].

\section{Wind Energy}

Wind energy is clean and renewable, the same way solar energy. There are different models of windmills. The horizontal axis windmill is the more known, widely used in wind farms for large energy amounts generation. This model is more limited to this kind of application due to costs and equipment size. There are other windmill model options recommended to use in smaller scale. Vertical windmill is smaller and cheaper, they can be assembled closer to the ground and resists more to turbulences. Despite those benefits, vertical windmills lose in profitability if compared to horizontal axis one [3].The Atlas do Potêncial Eólico Brasileiro from 2013, available the speed and direction of the wind in all Brazilian territory in different height. With this information is possible to previously study the best place to install the windmill [4].

\section{Biomass Energy}

Biomass is the energy production way with biggest growth potential in Brazil and worldwide, therefore is one of the main alternatives to center generation. By definition, biomass is any matter from animals or plants that can be transformed into thermic or electrical energy. Lots of models of digesters are available to produce energy using biomass. Some of them works by heating biomass to create steam that will generate energy. Biodigesters can also work though anaerobic digestion, which is material's decomposition through bacteria in a no air environment. The process used can also be fermentation, where sugars of plants are converted to alcohol. Due to it's large agriculture area, Brazil has enormous potential of power generation through this resource.

\section{Microgrids Working Worldwide}

Implement an microgrid in a rural property demands study of the energy potential in the area, as well as the best way to avail the resources. The small archipelago Islas Secas located on Panamá's shore has $90 \%$ of its energy provided by a microgrid. The installation at this archipelago is composed by solar panels that produces energy during the day and the exceeding charges batteries that works at night, silently, continually and with no gas emissions. Connected to the microgrid there are diesel generators for unpredicted cases, they can be turned on at any time. Another microgrid project already working happens in one hospital in Haiti, in one remote village. American students developed the project with solar panels which the generation capacity is $7,2 \mathrm{~kW}$. This installation also has one diesel generator for security [7].

\section{Quality Parameters}

To assure the rural property fed by the microgrid can trust the energy supply under any circumstances is essential to keep quality parameters into acceptable values. Some aspects that requires attention are harmonics, power factor, frequency, tension variation, tension flotation, transitional periods etc [6]. The constancy of the energy 
produced guarantee that equipment won't be damaged and allows sale of the surplus energy to other farmers or to the energy dealership. The choice of quality equipment to assembly the microgrid and proper installation are very important to assure quality parameters.

\section{DISCUSSION}

The renewable energy sources mentioned before in this article are one example of how much the electrical Brazilian system can expand without require massive investments of the government. Is important to remember that this power sources are not fully controllable, because relies on the weather. That's the reason why the ideal solution is this sources integration to reduce chances of energy depletion. For example: during a sunny day exploit sun energy, missing sun exploit wind energy and missing both is possible to use biodigesters. However, those tree resources are faded to burnout, that's why one diesel generator is necessary, or have the microgrid connected to the network to possible emergencies. Is also important to have batteries or capacitor bank connected to the microgrid to store the energy that's not being used. At Brazil, installation of microgrid in private property is very expensive

and not accessible to everyone. The creation of public policies that encourage this energy production system is fundamental.

\section{CONCLUSION}

Implementation of microgrids in Brazilian rural zones is one step towards the county development. Benefits government, energy dealership and the farmers. For the farmers it gives independency of the big generation plants and still allows sale of the exceeding energy to the dealership. To make that possible is necessary assure quality parameters mentioned. From the government perspective saves massive investments in infrastructure, which can be used to subsidize microgrid installation. It boosts country's economy creating new jobs, with development and sustainability. For the energy dealerships allows expand sales for the cities, once the network won't be overwhelmed anymore. Enables new business between farmers and dealership, through energy sales. Figure 2 shows shortly the microgrids benefits and what it demands. 


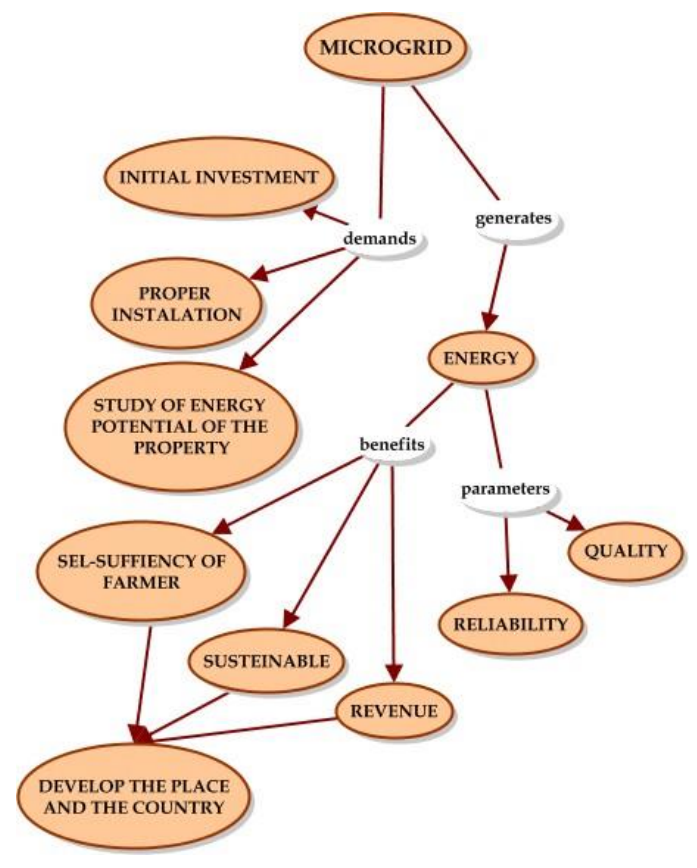

Figure 2. Microgrid's demands and benefits.

Acknowledgments: The authors thank UTFPR (Federal Technological University of Paraná) for the infrastructure offered for the development of this research, and COPEL for the support provided through the email exchange and the data provided on their site.

\section{REFERENCES}

1. Itaipu Binacional. Atlas Inédito Mostra Potencial Energético do Paraná. Disponível em: < https://www.itaipu.gov.br/sala-deimprensa/noticia/atlas- inedito-mostra-potencialenergeticodo-parana >. Acesso em: set. 2018.

2. Tiepolo, G. M.; Pereira, E. B.; Urbanetz Jr, J.; Pereira, S. V.; Goncalves, A. R.; Lima, F. J. L.; Costa, R. S., Alves, A. R. "Atlas de Energia Solar do Estado do Paraná". 1a Edição. Curitiba: UTFPR, 2017.

3. Tipos de Aerogeradores para Geração de Energia Elétrica. Disponível em: < http://www.cresesb.cepel.br/index.php?section=publicacoe s\&task=livro\&cid=1>. Acesso em: set. 2018.

4. Neiva, A. Dutra, R. Melo, S. Guedes, V. Cabrera, A. Almeida, W.Braz,R. Atlas do Potencial Eólico Brasileiro. Rio de Janeiro. 2017.

5. Atlas de Energia Elétrica no Brasil. Biomassa. Disponível em: < http://www2.aneel.gov.br/arquivos/pdf/atlas_par2_cap4. pdf>. Acesso em: set. 2018.

6. Rocha, J. Qualidade da Energia Elétrica. 2016. Disponível em: $\quad$ file:///C:/Users/Maria\%20Luiza/Downloads/Qualidade\%

20da\%20Energia\%20Eletrica\%20_\%20Apostila.pdf>. Acesso em: set. 2018.

7. Microgrid projects. Disponível em: < http://microgridprojects.com/>. Acesso em: set. 2018.

(C) 2018 by the authors. Submitted for possible open access publication under the terms and conditions of the Creative Commons Attribution (CC BY NC) license (http://creativecommons.org/licenses/by/4.0/). 